\title{
PLEISTOCENSKA POLEDENITEV BIOKOVA
}

\author{
Manja Žebre*, dr. Uroš Stepišnik**, Gregor Fabekovič****,Aleš Grlj****, \\ Simon Koblar***, Blaž Kodelja***, Valentina Pajk***, Katia Štefanić**** \\ *Groharjeva 8, SI-I24I Kamnik \\ **Oddelek za geografijo, Filozofska fakulteta Univerze v Ljubljani, Aškerčeva 2, SI-I000 \\ Ljubljana \\ ***Študent/ka geografije na Oddelku za geografijo Filozofske fakultete Univerze v Ljubljani \\ e-mail: manjazebre@gmail.com, uros.stepisnik@gmail.com
}

Izvirni znanstveni članek

COBISS 1.01

DOI: $10.4312 /$ dela.39.8.141-155

\section{Izvleček}

Biokovo je gorski masiv v obalnem delu Dinarskega gorstva na Hrvaškem. S podrobno morfografsko in morfometrično analizo najvišjega dela gorskega masiva smo določili obseg in značilnosti mlajšepleistocenske poledenitve. Izdelali smo rekonstrukcijo topografije ledenikov in izračunali višino njihove ravnovesne meje. Ugotovili smo, da sta bila severovzhodno pod vrhom Sveti Jure dva krniška ledenika s skupno površino $1 \mathrm{~km}^{2}$, ravnovesna meja pa je bila na višini $1515 \mathrm{~m}$.

Ključne besede: poledenitev, pleistocen, ravnovesna meja ledenikov, Hrvaška, Biokovo, Dinarsko gorstvo

\section{PLEISTOCENE GLACIATION OF THE BIOKOVO MASSIF}

\begin{abstract}
Biokovo massif is situated in the coastal part of the Dinaric Mountains in Croatia. Detailed morphographic and morphometric analysis of the highest parts of the massif were used to determine the extent and characteristics of Late Pleistocene glaciation. The reconstruction of glaciers and calculations of equilibrium line altitude (ELA) were carried out. Our research revealed that on the north-eastern side of the highest peak Sveti Jure two cirque glaciers with an overall area of $1 \mathrm{~km}^{2}$ were formed and their ELA was $1515 \mathrm{~m}$ a.s.l.
\end{abstract}

Key words: glaciation, Pleistocene, equilibrium line altitude (ELA), Croatia, Biokovo, Dinaric Mountains 


\section{UVOD}

Gorski masiv Biokovo leži v srednji Dalmaciji in je del Zunanjih Dinaridov. Na severovzhodu je omejen z nižjim reliefom med Žeževico in Rastovcem ter Župo in Raščanami, proti jugovzhodu meji na Rilič, na severozahodu na Omiško Dinaro ter na jugozahodu na Jadransko morje. Dolžina Biokova je 36 km, širina v najširšem delu pa $9,5 \mathrm{~km}$. Najvišji vrh je Sveti Jure, ki z nadmorsko višino $1762 \mathrm{~m}$ izrazito presega pretežno planotasto površje na višini od 1300 do $1400 \mathrm{~m}$.

Celotno območje Biokova je kraško, kar se kaže v popolni odsotnosti površinskih voda ter v značilni izoblikovanosti površja. Med posameznimi kopastimi vrhovi v vrhnjem delu planotastega ovršja prevladujejo raznovrstne kraške kotanje, ki na gosto prekrivajo celotno površje. Poleg kraških oblik so v bližini najvišjega vrha tudi sledovi ledeniške erozije in akumulacije, kar navaja že Roglić (1931; 1935). Sledove poledenitve na Biokovu pa so nekateri raziskovalci (Telbisz, Dragušica, Nagy, 2009; Protrka in sod., 2011) identificirali tudi v nižjih delih planote in na njenih pobočjih.

Namen raziskave je reinterpretacija dosedanjih ugotovitev obsega pleistocenske poledenitve $\mathrm{z}$ rekonstrukcijo obsega, topografije in ravnovesne meje pleistocenskih ledenikov na Biokovu.

\section{GEOLOŠKE, GEOMORFOLOŠKE IN KLIMATSKE ZNAČILNOSTI BIOKOVA}

Povečini karbonatna sestava kamnin na Biokovu se kaže v popolni prevladi kraškega geomorfnega sistema. Območje Biokova je globoki raztočni kras, v katerem je globina vadozne cone okoli $1000 \mathrm{~m}$. V podzemlju prevladujejo brezna vadozne cone, med katerimi je najgloblje Amfora z globino 788 m (Bušelić, Ozimec, 2008). Kraški izviri so na litološkem stiku s fliši v podnožju gorovja; pogoste so tudi brojnice (Benček, 2008; Matić in sod., 2012). Vršni del Biokova je izrazito skalnat z veliko pestrostjo kraških oblik, zlasti drobnih korozijskih oblik, škrapelj, vrtač, kopastih vrhov in kont. Cvijić (1909) je to območje opredelil kot eno najbolj zakraselih v celotnih Dinaridih. Gostota vrtač, zlasti pa kont je tako velika, da nekateri avtorji (Telbisz, Dragušica, Nagy, 2009) površje Biokova opredeljujejo celo kot poligonalni kras. Konte uvrščamo med klimatsko pogojene kraške oblike, katerih oblikovanje je vezano na območja pleistocenske poledenitve ali njihovo neposredno bližino. Konte na Biokovu, ki jih lokalno imenujejo 'bogodoli' (Roglić, 2005), imajo strma in skalnata pobočja, v njihovih dneh pa so nakopičeni podorni bloki in grušč. V kontah so pogosto vhodi v jame in brezna (Telbisz, Dragušica, Nagy, 2009).

Območje Biokova geotektonsko pripada narivu Biokova, ki je narinjen na sinklinorij Makarskega primorja. Gorski masiv Biokovo gradijo plitvomorske karbonatne kamnine Dinarske karbonatne platforme mezozojske starosti, ki so narinjene na eocenske flišne kamnine. Strmo strukturno stopnjo na jugozahodu gradijo apnenci in breče srednjejurske starosti. Zgornjejurski apnenci z vložki dolomitov se pojavljajo severovzhodno nad pasom srednjejurskih kamnin in poleg pobočij gradijo tudi vršni 
del gorskega masiva. Najvišji deli gorskega masiva in njegova severovzhodna pobočja so zgrajeni pretežno iz spodnjekrednih apnencev z lečami breč in dolomitov ter zgornjekrednih apnencev, ki se v manjši meri pojavljajo tudi ob jadranski obali. Iz obdobja eocena, ko se je pričelo narivanje tektonske enote Biokovo na tektonsko enoto Makarsko primorje, so apnenci in fliši ob jadranski obali in v posameznih ožjih pasovih na severovzhodnih pobočjih. Kvartarne starosti so grušči in breče na jugozahodnih pobočjih ter ledeniški sedimenti v okolici najvišjega vrha Biokova (Benček, 2008; Osnovna geološka karta SFRJ, list Omiš, 1977; Osnovna geološka karta SFRJ, list Imotski, 1978; Osnovna geološka karta SFRJ, list Ploče, 1979).

Podnebje preučevanega območja se spreminja od sredozemskega ob obali proti gorskemu na najvišjih delih Biokova. Hitro naraščanje nadmorske višine na kratki razdalji izrazito vpliva na razliko v povprečni letni temperaturi, ki je v Makarski $15,5{ }^{\circ} \mathrm{C}$, na vrhu Sveti Jure pa $3,9^{\circ} \mathrm{C}$, in na razliko v povprečni letni količini padavin, ki je na primorski strani 1100-1300 mm, na najvišjih delih masiva 2000-2500 mm, na severovzhodni strani Biokova pa 1300-1500 mm. Značilna za Biokovo je tudi burja, katabatični veter, ki lahko v sunkih presega 200 km/h (Klimatski atlas Hrvatske ..., 2008).

Slika 1: Lokacija Biokova

Figure 1: Location of Biokovo

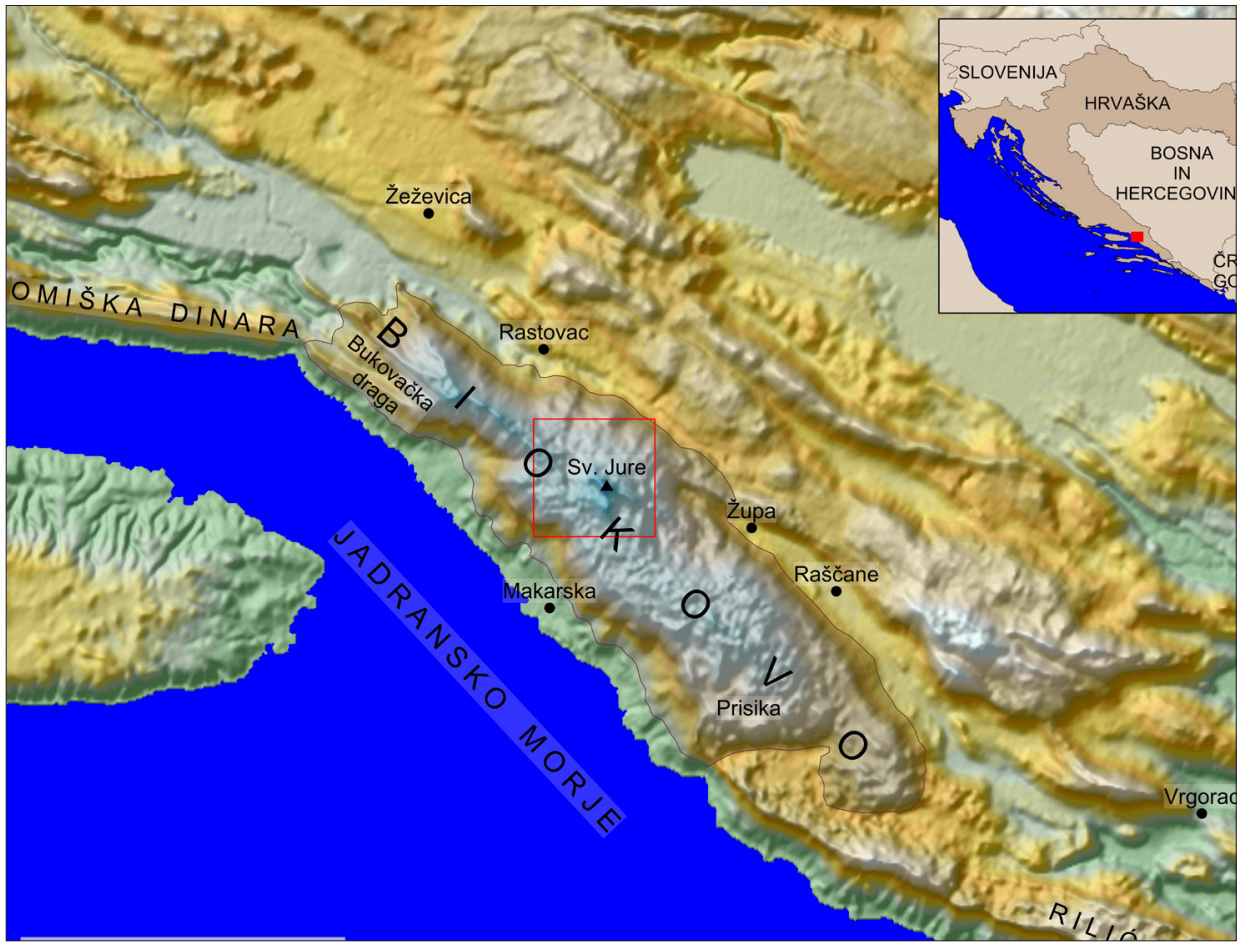




\section{PREGLED DOSEDANJIH RAZISKAV POLEDENITVE BIOKOVA}

Obstoj pleistocenske poledenitve na Biokovu je prvi opazil Roglič (1931; 1935). Identificiral je dve krnici severovzhodno od vrha Sveti Jure, pod in v njih pa je našel gradivo ledeniškega izvora. Opisal ga je kot nezaobljeno in neoraženo, kar naj bi bila posledica majhne dinamike premikanja ledenika. Ugotovil je, da sta bila severovzhodno od vrha Sveti Jure dva manjša krniška ledenika, ki sta zavzemala okoli $1 \mathrm{~km}^{2}$ površine. Predvideval je obstoj ledenika tudi v neizraziti kotanji vzhodno od vrha Sveti Jure, na kar naj bi nakazovali nekoliko slabše ohranjeni ledeniški sledovi. Glede na poglobljenost krnic in količino morenskega gradiva je trdil, da je bila na Biokovu le ena poledenitev, ki pa je ni postavil v časovni okvir. Snežno mejo je določil na nadmorski višini 1570 m.

Več kot sedemdeset let kasneje so o ledeniških oblikah v Prisiki na jugu Biokova pisali Telbisz, Dragušica in Nagy (2009). Na nenavadno nizkih nadmorskih višinah (1100 $\mathrm{m}$ in $900 \mathrm{~m}$ ) so identificirali eratične skale in ostanke nekdanjih krnic. Nekatere kotanje jugovzhodno od vrha Sveti Jure so opredelili kot nivacijske kotanje. Preučevanje sledov poledenitve manjšega obsega naj bi bilo po njihovih trditvah problematično, saj so manjše krnice in nivacijske kotanje podobne kraškim kotanjam. Poleg tega naj bi bilo morensko gradivo zaradi korozije slabo ohranjeno.

Najnovejša literatura (Protrka in sod., 2011) navaja, da so sledovi poledenitve tudi v Bukovački dragi na severozahodu Biokova. Na nadmorski višini od 1030 do $1050 \mathrm{~m}$ so avtorji identificirali tri drumline in jim pripisali würmsko starost. Izoblikovanost Bukovačke drage v obliki črke 'U' so interpretirali kot rezultat ledeniške erozije.

\section{METODOLOGIJA RAZISKAVE}

Raziskavo sledov poledenitve na Biokovu smo pričeli s pregledom literature in podrobno analizo kartografskega gradiva. Sledila je terenska morfografska analiza ledeniških oblik. Topografijo ledenikov smo rekonstruirali na osnovi morfometrične analize bočnih in čelnih moren ter digitalnega modela nadmorskih višin. Podatke o topografiji ledenikov smo nato uporabili pri izračunih njihove površine in ravnovesne meje.

\section{I. Morfografska in morfometrična analiza}

Morfografska analiza je temeljila na terenski identifikaciji ledeniških erozijskih in akumulacijskih oblik ter morfografskem kartiranju v merilu $1: 25.000$. Morfometrično analizo ledeniških oblik smo opravili na terenu ter $\mathrm{z}$ analizo digitalnega modela nadmorskih višin in kartografskega gradiva.

\subsection{Rekonstrukcija topografije ledenikov}

Rekonstrukcijo topografije ledenikov smo izdelali s programom Golden Software Surfer. Obseg ledenika v spodnjem delu smo določili na osnovi lokacij bočnih in čelnih moren. 
Nato smo mejo poledenitve na podlagi izoblikovanosti površja in lokacij bočnih moren ekstrapolirali proti vrhnjemu delu ledenika. Zgornjo mejo ledenika smo postavili pod obodom krnice, oziroma na pobočje z naklonom, manjšim od 60 stopinj (Meierding, 1982). Površje ledenika smo rekonstruirali tako, da so ledeniške plastnice konkavne nad in konveksne pod ravnovesno mejo; stopnja konkavnosti in konveksnosti pa se povečuje z oddaljenostjo od ravnovesne meje (Porter, 1975; Carr, Coleman, 2007; Carr, Lukas, Mills, 2010).

\subsection{Rekonstrukcija ravnovesne meje}

Pleistocensko ravnovesno mejo na Biokovu smo na osnovi razpoložljivih morfometričnih podatkov ter tipa in geometrije ledenikov izračunali s pomočjo treh metod: metodo deleža akumulacijskega dela ledenika (Porter, 2000), metodo obtežene površine ledenika (Sissons, 1974) in metodo srednje višine ledenika (Benn, Lehmkuhl, 2000). Za aplikacijo prvih dveh metod je potrebna predhodna rekonstrukcija topografije ledenika. Poleg tega je pri metodi deleža akumulacijskega dela ledenika potrebno predpostaviti razmerje med površino akumulacijskega in ablacijskega dela ledenika glede na vrsto ledenika in njegovo geometrijo. Empirična preučevanja današnjih ledenikov na srednjih in visokih geografskih širinah so pokazala, da je v stabilnih pogojih delež akumulacijskega dela ledenika običajno med 50 in 80 \% celotne površine (Meier, Post, 1962). Toda razmerja med akumulacijskim in ablacijskim delom ledenika se razlikujejo glede na površino ledenika (Kern, László, 2010). Za krniške in dolinske ledenike s površino od 0,1 do 1 km² je bilo ugotovljeno, da je delež akumulacijskega dela 44 ( \pm 7$)$ \% (Kern, László, 2010). To vrednost smo uporabili tudi pri naših izračunih ravnovesne meje, saj je bila površina pleistocenskih ledenikov na Biokovu manjša od $1 \mathrm{~km}^{2}$.

Določanje ravnovesne meje po metodi srednje višine ledenika je precej bolj enostavno. Pri slednji moramo poznati le nadmorske višine zgornje in spodnje meje ledenika. Čeprav je določanje spodnje meje ledenika na podlagi čelnih moren ali predledeniških vršajev relativno enostavno, pa je določanje zgornje meje nekdanjega ledenika na območju krnice precej subjektivno, kar lahko pripelje do napake nekaj deset metrov (Porter, 2000).

\section{POLEDENITEV BIOKOVA}

Na podlagi morfografske in morfometrične analize so bile v okolici najvišjega vrha Sveti Jure identificirane in opisane številne erozijske in akumulacijske ledeniške oblike. Slednje so zgrajene iz nesprijetega in sprijetega ledeniškega materiala. Sprijet ledeniški material gradi dobro ohranjene grebene čelnih in bočnih moren ter zaplate talnih moren, na katerih ni značilnih sledov korozijskega preoblikovanja. Iz nesprijetega ledeniškega materiala so zaplate moren, $\mathrm{v}$ katerih grebeni čelnih in bočnih moren niso ohranjeni. Na površju teh moren so dobro razvite kraške oblike, kot so žlebiči in celo škraplje. Kljub temu da morfokronoloških analiz ledeniških akumulacij nismo opravili, je po sprijetosti in sledovih kemičnega preperevanja očitno, da so sprijete ledeniške akumulacije iz starejših poledenitvenih faz, medtem ko nesprijete predstavljajo akumulacijo iz viška zadnje poledenitve. 
Rekonstrukcija topografije ledeniškega površja in višine ravnovesne meje temelji na nesprijetih ledeniških akumulacijah. Starejše morene niso ohranjene v tolikšni meri, da bi bila mogoča topografska in paleoklimatska rekonstrukcija takratnih ledenikov.

\section{I. Sledovi poledenitve}

Tik pod najvišjim vrhom Biokova sta dve krnici s severovzhodno ekspozicijo, ki ju navaja že Roglić (1931; 1935). V vrhnjih delih krnic in v njunih dneh je obrušeno ledeniško površje z manjšimi lašti in številnimi ledeniškimi grbinami. Južna krnica je omejena z vrhovoma Sveti Jure (1762 m) na jugozahodu in Seveljev brig (1548 m) na severovzhodu. Najvišji del oboda je tik pod vrhom Sveti Jure, dno pa na nadmorski višini od 1460 do $1430 \mathrm{~m}$. Dno krnice, v katerem sta dve živoskalni kotanji, je mestoma prekrito s talno moreno. Krnico zapira nekoliko privzdignjen krniški prag, ki ga povsem prekriva morenski material. Na zahodnem pobočju Seveljevega briga je izrazita bočna morena na nadmorski višini $1500 \mathrm{~m}$, pod njo pa so manjše bočne in čelne morene umikalnih stadijev ledenika (slika 2).

Slika 2: Geomorfološka karta sledov poledenitve na Biokovu Figure 2: Glacial geomorphological map of Biokovo

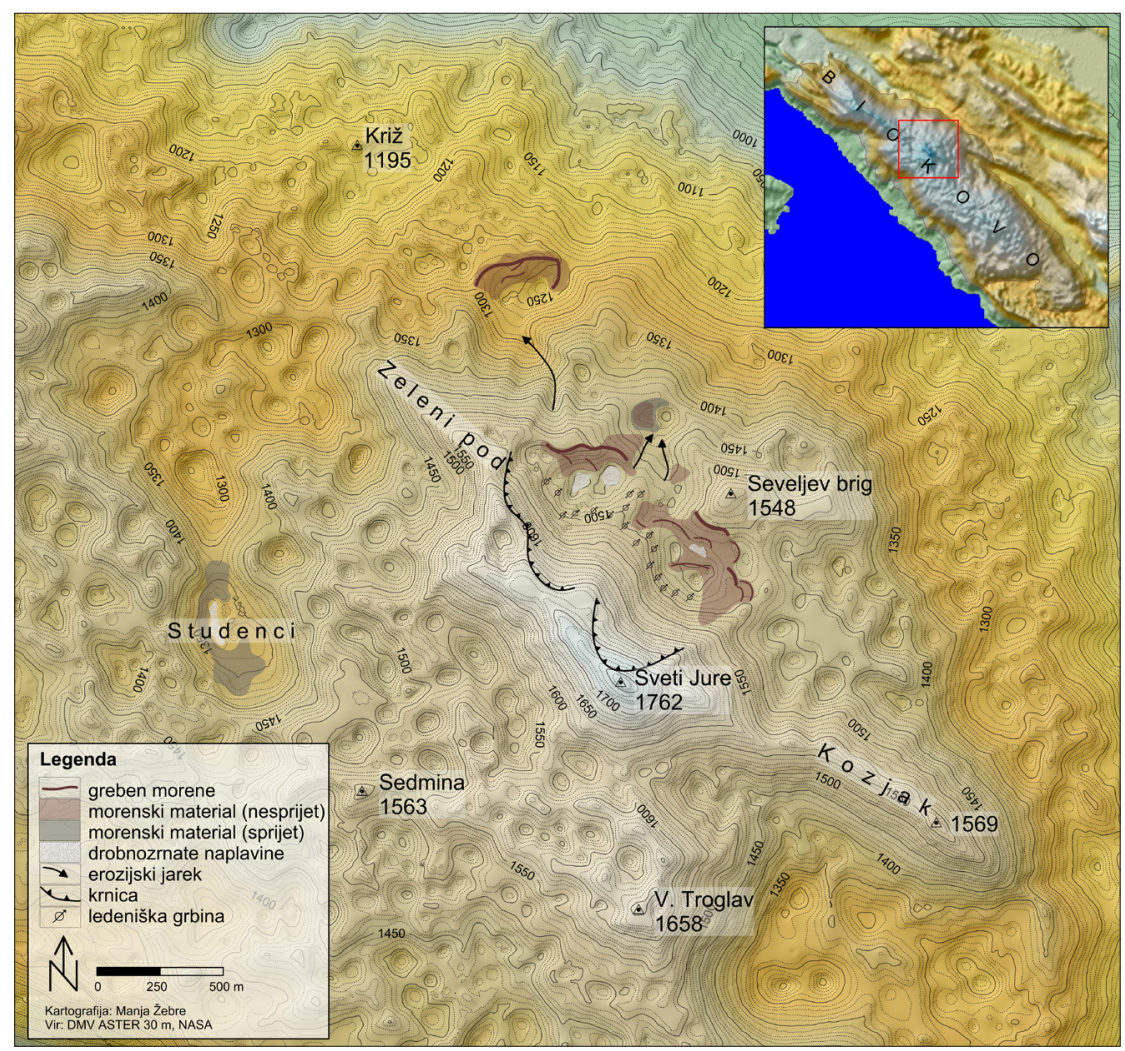


Severna krnica leži severno pod vrhom Sveti Jure, med grebenom Zeleni pod na zahodu in vrhom Seveljev brig na vzhodu. Najvišji del oboda sega do nadmorske višine 1650 m, dno pa je med 1440 in 1460 m. Na dnu krnice sta dve kotanji, zapolnjeni z drobnozrnatim materialom podledeniških tokov. Več kot $300 \mathrm{~m}$ dolga bočna morena z vrhnjim delom na nadmorski višini 1500 m poteka po južnem pobočju krnice in se zaključi tik nad krniškim pragom na 1470 m nadmorske višine. Na južnem pobočju krnice sta tudi dve manjši umikalni moreni. Na pobočju pod ledeniškima pragovoma obeh krnic sta dva erozijska jarka nekdanjih podledeniških tokov, ki se zaključita v kotanji severovzhodno od vrha Seveljev brig (slika 3). Celotno pobočje vzdolž erozijskih jarkov in vsa pobočja kotanje so prekriti z morenskim materialom.

Obod severne krnice je v skrajnem severnem delu znižan, pod njim pa je na strmem pobočju erozijski jarek podledeniškega toka, ki se nadaljuje v veliko kotanjo na severu z dnom na nadmorski višini okoli $1230 \mathrm{~m}$. Izrazit bočno-čelni morenski kompleks, visok do $50 \mathrm{~m}$, v celoti prekriva severni obod kotanje. Zaključi se na vzhodnem delu kotanje, nad strmo reliefno stopnjo. Na dnu kotanje je nekaj manjših umikalnih moren.

Sledove starejših poledenitev smo identificirali v konti s toponimom Studenci, zahodno od vrha Sveti Jure (slika 4). Sprijet ledeniški material deloma prekriva dno kotanje na nadmorski višini 1340 m ter celoten severni obod, ki sega do nadmorske višine 1360 m.

Slika 3: Erozijski jarek na pobočju pod ledeniškim pragom severne krnice; desno od jarka je bočna morena, levo najvišji vrh Biokova, Sveti Jure (foto: M. Žebre)

Figure 3: Erosional gully on the slope below the northern cirque threshold; lateral moraine is to the right and the highest peak of Biokovo, Sveti Jure, is to the left of the gully (photo: M. Žebre)

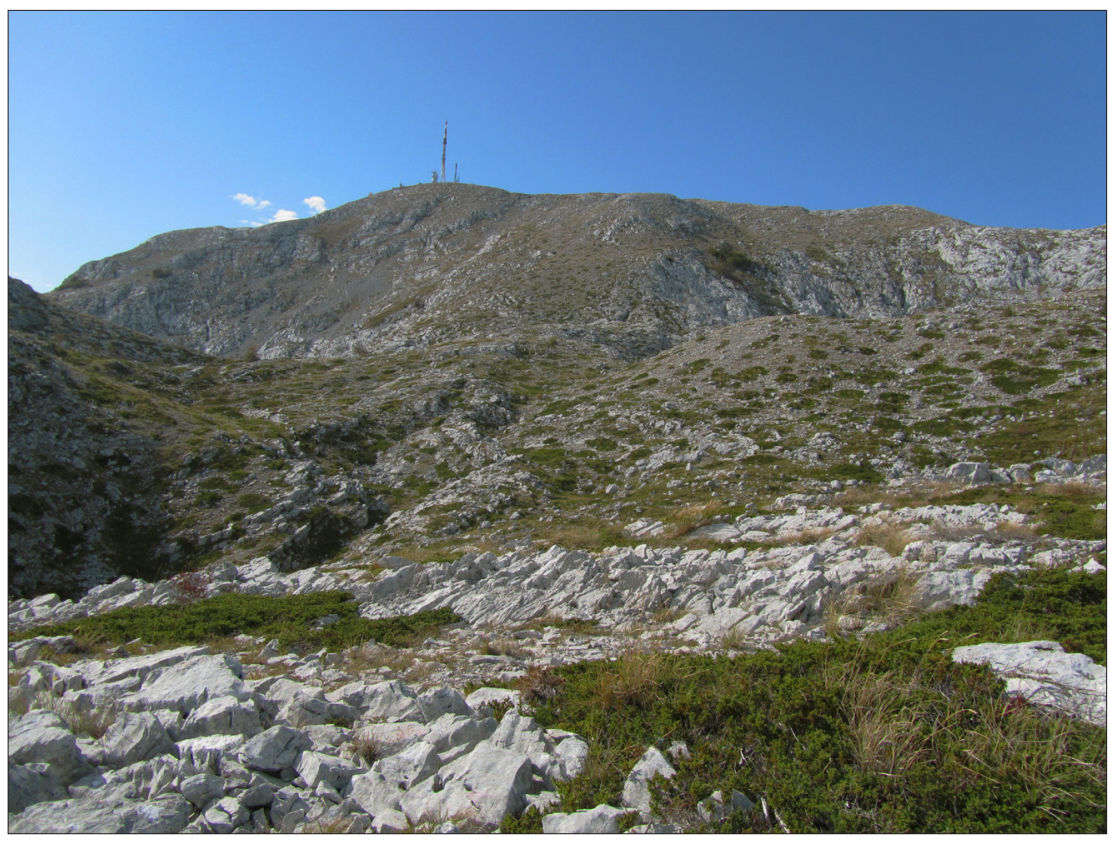


V okviru naših raziskav poledenitve Biokova smo kljub nenavadno nizkim nadmorskim višinam pregledali tudi vsa območja, na katerih predhodna literatura navaja obstoj ledeniških oblik. V Bukovački dragi na nadmorski višini med 1030 in 1050 m ledeniških oblik, natančneje drumlinov, ki jih opisujejo Protrka in sodelavci (2011), nismo našli. Pobočja Bukovačke drage gradijo navpični skladi apnencev, dno pa fliš. Oblike, ki so jih identificirali kot drumline, so po našem mnenju manjši flišni hrbti, ki jih mestoma prekriva apnenčasti grušč. Prav tako nismo našli sledov poledenitve na območju s toponimom Prisika na nadmorski višini med 900 in 1100 m (Telbisz, Dragušica, Nagy, 2009). Na celotnem območju je izključno kraško površje s kotanjami, ki so jih avtorji najverjetneje napačno interpretirali kot kotanje ledeniškega izvora.

Slika 4: Morenski material v konti Studenci (foto: B. Kodelja)

Figure 4: Morainic material in Studenci karst depression (photo: B. Kodelja)

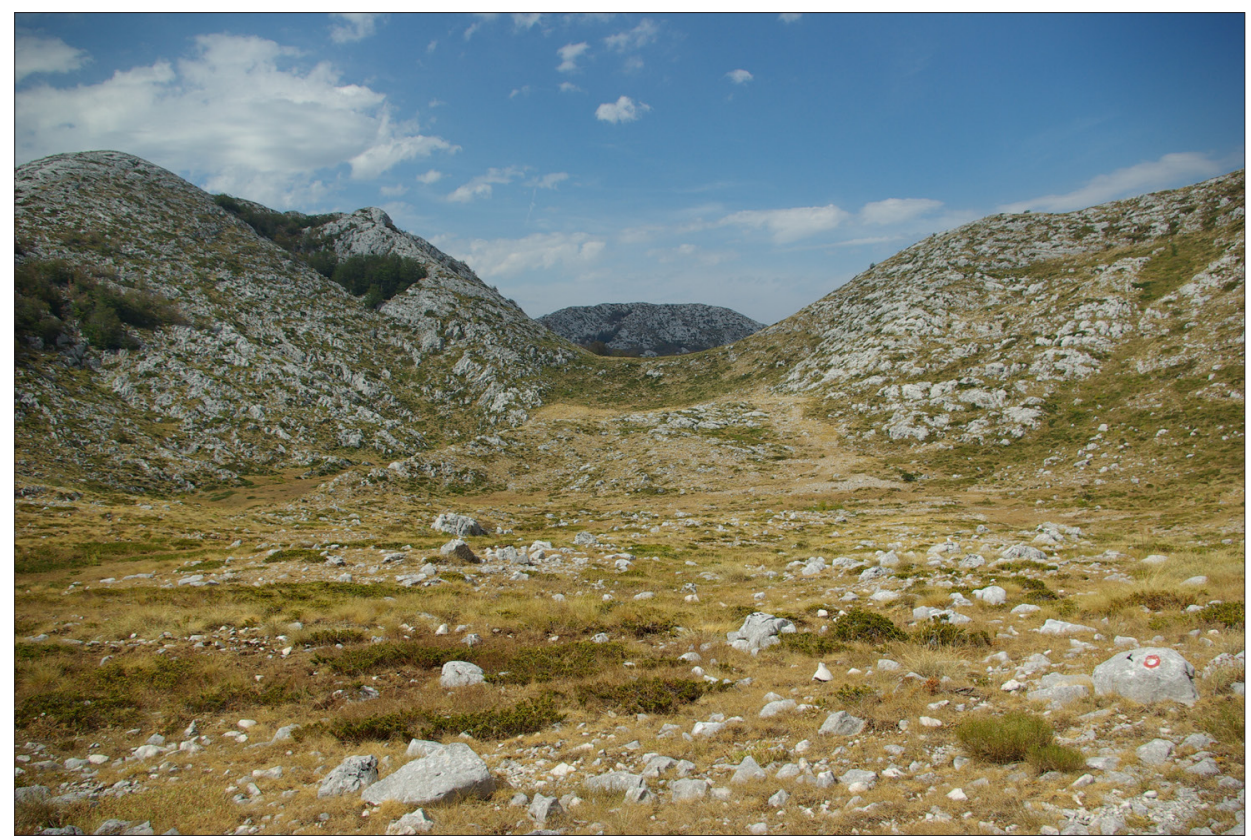

\subsection{Topografija ledenikov}

$\mathrm{Na}$ Biokovu smo identificirali krniški tip poledenitve. Poledenitev je zavzemala le okoli $0,8 \mathrm{~km}^{2}$ površine. Severno in severovzhodno od vrha Sveti Jure sta obstajala dva krniška ledenika (slika 5). Največja debelina ledu v južni krnici je dosegala 70 m, led pa je odtekal zahodno od vrha Seveljev brig proti severu. Na pregibu, preko katerega je ledenik iz južne krnice polzel proti severu, je bila debelina ledu $40 \mathrm{~m}$. V severni krnici je največja debelina ledu znašala $80 \mathrm{~m}$, led pa je odtekal v dve smeri. Del ledenika iz 
severne krnice, ki se je premikal preko krniškega praga proti vzhodu, se je v kotanji severno pod vrhom Seveljev brig združil z ledenikom iz južne krnice. Skupni ledenik se je končal nad strmim reliefnim pregibom na nadmorski višini $1420 \mathrm{~m}$. Drugi del ledu iz severne krnice je odtekal proti severu preko strmega pobočja v dno kotanje, ki leži okoli 300 m nižje. Ledenik se je prav tako zaključil nad strmim reliefnim pregibom na nadmorski višini $1245 \mathrm{~m}$.

Slika 5: Rekonstrukcija mlajšepleistocenske poledenitve na Biokovu

Figure 5: Reconstruction of Late Pleistocene glaciers on Biokovo

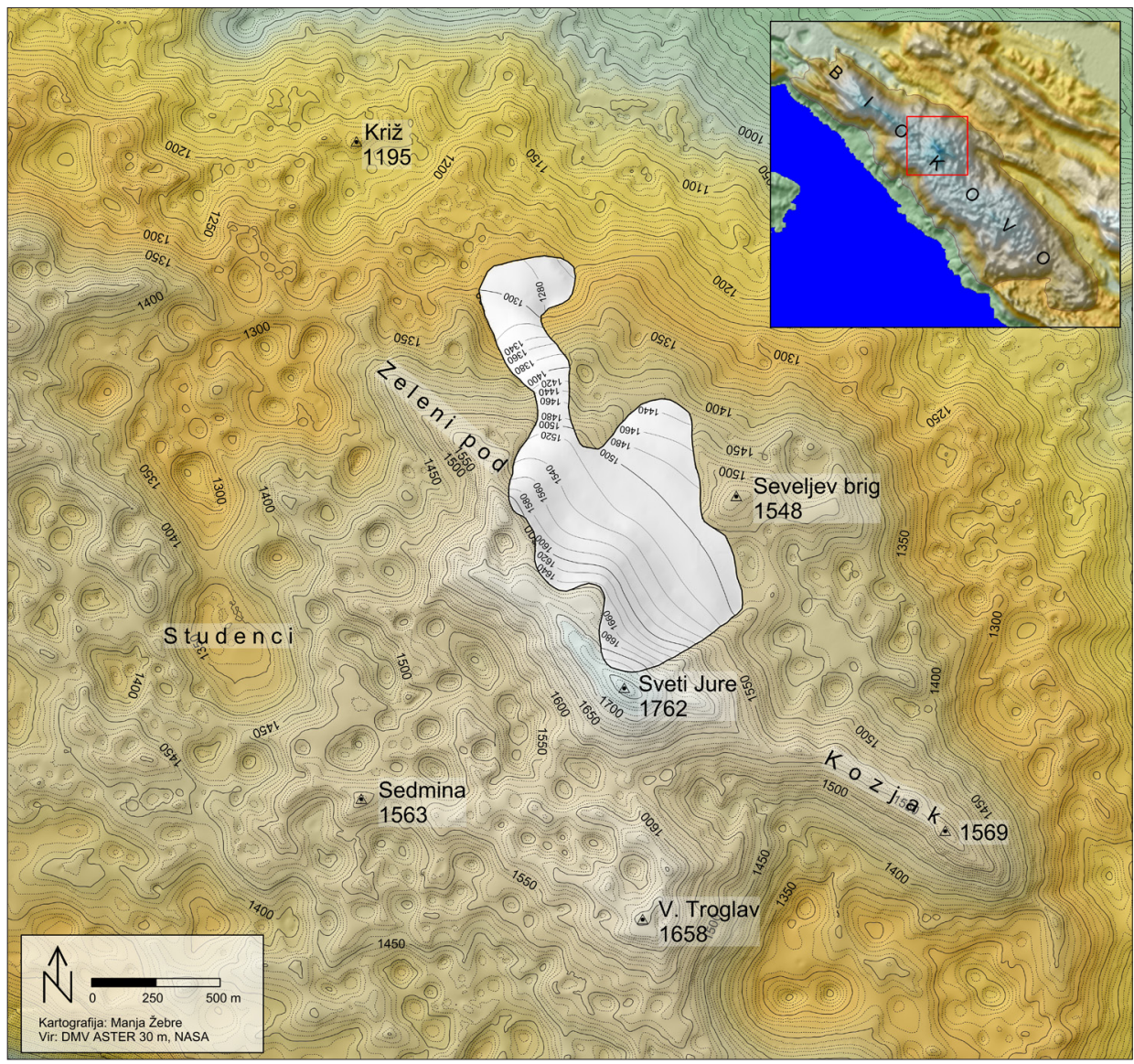


Slika 6: Kotanja severovzhodno od Zelenega poda, v katero je segal ledenik iz severne krnice; obod kotanje na levi strani fotografije je prekrit z bočno moreno (foto: M. Žebre)

Figure 6: Glacier from the northern cirque reached down into karst depression northeast of Zeleni pod; in the photo to the left is the rim of depression covered by lateral moraine (photo: M. Žebre)

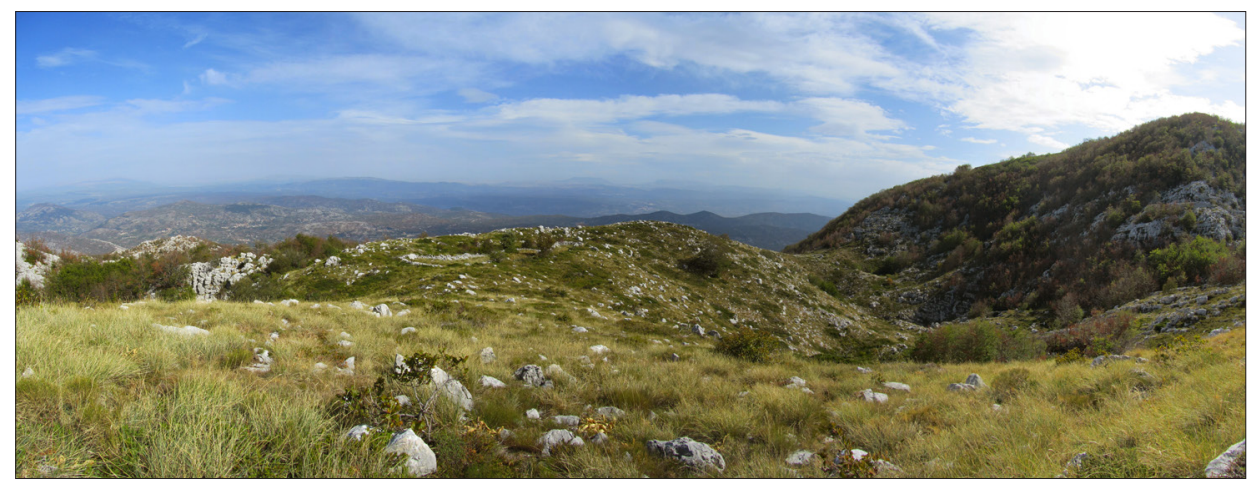

\subsection{Ravnovesna meja ledenikov}

Za izračun ravnovesne meje smo uporabili tri metode, povprečje njihovih rezultatov pa smo vzeli kot najboljši približek višine ravnovesne meje ledenikov na Biokovu. Po metodi deleža akumulacijskega dela ledenika je bila ta meja na nadmorski višini $1530 \mathrm{~m}$. Po metodi obtežene površine ledenika smo izračunali, da se je ravnovesna meja nahajala na nadmorski višini 1505 m, po metodi srednje višine ledenika pa je bila na višini 1515 m. Ravnovesna meja na Biokovu je bila torej v povprečju na nadmorski višini $1515 \mathrm{~m}$.

\section{ZAKLJUČEK}

Glavni namen raziskave je bil reinterpertacija dosedanjih ugotovitev o poledenitvi Biokova. Območje preučevanja je bila okolica vrha Sveti Jure na Biokovu, pregledali pa smo tudi vse lokacije, kjer so predhodni raziskovalci identificirali sledove poledenitve.

$\mathrm{V}$ okviru raziskave smo identificirali sprijete in nesprijete ledeniške akumulacije. Sprijete akumulacije smo našli v konti Studenci zahodno od vrha Sveti Jure, nesprijete pa na njegovi severovzhodni strani. Za razliko od dobro ohranjenih grebenov moren, ki jih gradi nesprijet morenski material, so vse sprijete akumulacije slabo ohranjene, na njih pa so predvsem zaradi kemičnega preperevanja že oblikovane škraplje in manjše kraške kotanje. Ker morfokronoloških analiz ledeniških akumulacij nismo opravili, smo njihovo relativno starost določili na osnovi sprijetosti in kemične preperelosti morenskega materiala.

$\mathrm{Na}$ podlagi analogije $\mathrm{z}$ absolutnimi datacijami ledeniških akumulacij na Orjenu (Hughes in sod., 2010) in gorskih masivih osrednje Črne gore (Hughes in sod., 2011) smo sklepali na časovno razporeditev poledenitev na Biokovu: največji obseg poledenitev na Dinarskem gorstvu je bil v srednjem pleistocenu (MIS 12 in MIS 6), v mlajšem 
pleistocenu (MIS 5d-2) pa je bila poledenitev omejena na manjše dolinske in krniške ledenike. Tako smo dobro ohranjenim nesprijetim ledeniškim akumulacijam pripisali mlajšepleistocensko starost, medtem ko za slabo ohranjene sprijete akumulacije sklepamo, da so starejše. Vse nadaljnje rekonstrukcije poledenitve in ravnovesne meje ledenikov so bile izdelane na osnovi morfografske in morfometrične analize mlajšepleistocenskih nesprijetih ledeniških akumulacij.

Sledove mlajšepleistocenske poledenitve smo identificirali severovzhodno od vrha Sveti Jure na nadmorskih višinah od 1240 do $1500 \mathrm{~m}$. Drugje kljub navedbam predhodne literature (Protrka in sod., 2011; Telbisz, Dragušica, Nagy, 2009) nismo našli ledeniških oblik. Na osnovi morfografskih in morfometričnih podatkov o ledeniških oblikah smo izdelali rekonstrukcijo topografije ledenikov. Ugotovili smo, da sta bila na Biokovu dva manjša krniška ledenika, ki sta skupaj zavzemala okoli $0,8 \mathrm{~km}^{2}$ površine, kar se v večji meri sklada z raziskavami Roglića $(1931 ; 1935)$; po njegovih navedbah naj bi ledeniki zavzemali okoli $1 \mathrm{~km}^{2}$ površine.

Čeprav smo sledove mlajšepleistocenske poledenitve našli le severovzhodno od vrha Sveti Jure, predpostavljamo, da so bile zaradi temperaturne inverzije z ledom zapolnjene tudi vse konte pod višino snežne meje, kar je bilo ugotovljeno tudi na Trnovskem gozdu (Kodelja, Žebre, Stepišnik, 2013). Sledov ledeniške erozije v kontah kljub detajlnemu pregledu nismo našli, saj se je najverjetneje v njih led le zadrževal in ni polzel preko njihovega oboda.

Ravnovesna meja na Biokovu se je glede na izračune po metodah deleža akumulacijskega dela ledenika, obtežene površine ledenika in srednje višine ledenika v povprečju nahajala na nadmorski višini 1515 m, kar je za 55 m nižje od vrednosti, ki jo navaja Roglić (1931; 1935). V primerjavi z nekaterimi gorskimi masivi v obalnem delu Dinarskega gorstva, kot so Velebit, Orjen in Lovčen, je bila ravnovesna meja na Biokovu za 200-300 m višja (Belij, 1985; Bognar, Faivre, Pavelić, 1991; Bognar, Faivre, 2006; Hughes in sod., 2010; Stepišnik in sod., 2009; Stepišnik, Žebre, 2011). To lahko pojasnimo z bistveno nižjo količino padavin, ki jo prejme Biokovo v primerjavi z ostalimi gorovji. Količina padavin na najvišjih delih Biokova je okoli $2500 \mathrm{~mm}$, na Velebitu okoli $3500 \mathrm{~mm}$ (Klimatski atlas Hrvatske ..., 2008), medtem ko Orjen in Lovčen prejmeta več kot 4500 mm (Magaš, 2002; Radovanović, 1994).

Literatura navaja različne dimenzije gorovij, ki so potrebne za oblikovanje ledenikov. Manley (1955) navaja, da se ledena kapa na kilometer širokem gorovju oblikuje, kadar se gorovje dviga vsaj $300 \mathrm{~m}$ nad lokalno ravnovesno mejo. Østrem (1966) je ugotovil, da je najnižja kritična višina za formiranje ledenikov običajno $100 \mathrm{~m}$ nad klimatsko snežno mejo, ki v grobem sovpada z ravnovesno mejo na toplih ledenikih. Ozek greben Svetega Jureta sega okoli $250 \mathrm{~m}$ nad ugotovljeno ravnovesno mejo, kar očitno ni zadostovalo za nastanek obsežnejše poledenitve. Vsekakor pa smo našli slabo ohranjene sledove starejših poledenitev na veliko večjem območju kot sledove mlajšepleistocenske poledenitve. To se sklada z rezultati morfokronoloških raziskav sledov poledenitev v Sredozemlju, da so bile srednjepleistocenske (MIS 12 in MIS 6) poledenitve obsežnejše od mlajšepleistocenskih (npr. Hughes in sod., 2006; Hughes in sod., 2010; Hughes in sod., 2011). 


\section{Viri in literatura}

Belij, S., 1985. Glacijalni i periglacijalni reljef južnog Velebita. Beograd, Srpsko geografsko društvo, 68 str.

Benček, Đ., 2008. Geologija Biokova. V: Ozimec, R. (ur.). Biokovo. Zagreb, Graphis, str. 29-49.

Benn, D. I., Lehmkuhl, F., 2000. Mass balance and equilibrium-line altitudes of glaciers in high-mountain environments. Quaternary international, 65-66, str. 15-29.

Benn, D. I., Evans, D. J. A., 1998. Glaciers and glaciation. London, Arnold, 734 str.

Bognar, A., Faivre, S., 2006. Geomorphological traces of the younger Pleistocene glaciation in the central part of the Velebit Mt. Hrvatski geografski glasnik, 68, 2, str. 19-30.

Bognar, A., Faivre, S., Pavelić, J., 1991. Tragovi oledbe na Sjevernom Velebitu. Geografski glasnik, 53, str. 27-39.

Bušelić, S., Ozimec, R., 2008. Speleologija Biokova. V: Ozimec, R. (ur.). Biokovo. Zagreb, Graphis, str. 49-72.

Carr, S. J., Coleman, C. G., 2007. An improved technique for the reconstruction of former glacier mass-balance and dynamics. Geomorphology, 92, 1-2, str. 76-90.

Carr, S. J., Lukas, S., Mills, S. C., 2010. Glacier reconstruction and mass-balance modelling as a geomorphic and palaeoclimatic tool. Earth surface processes and landforms, 35,9 , str. $1103-1115$.

Cvijić, J., 1909. Bildung und Dislozierung der Dinarischen Rumpfflächen. Gotha, Petermanns geographische Mitteilungen, $40 \mathrm{str}$.

DMV ASTER 30 m. NASA. URL: http://asterweb.jpl.nasa.gov/gdem.asp (Citirano 5. 2. 2013).

Hughes, P. D., Woodward, J. C., Gibbard, P. L., Macklin, M. G., Gilmour, M. A., Smith, G. R., 2006. The glacial history of the Pindus mountain, Greece. Journal of geology, 114, 4, str. 413-434.

Hughes, P. D., Woodward, J. C., van Calsteren, P. C., Thomas, L. E., Adamson, K. R., 2010. Pleistocene ice caps on the coastal mountains of the Adriatic Sea. Quaternary science reviews, 29, 27-28, str. 3690-3708.

Hughes, P. D., Woodward, J. C., van Calsteren, P. C., Thomas, L. E., 2011. The glacial history of the Dinaric Alps, Montenegro. Quaternary science reviews, 30, 23-24, str. 3393-3412.

Kern, Z., László, P., 2010. Size specific steady-state accumulation-area ratio: an improvement for equilibrium-line estimation of small palaeoglaciers. Quaternary science reviews, 29, 19-20, str. 2781-2787.

Klimatski atlas Hrvatske 1961-1990, 1971-2000. 2008. Zaninović, K., Gajić-Čapka, M., Perčec Tadić, M., Milković, J., Vučetić, M. (ur.). Zagreb, Državni hidrometeorološki zavod, 200 str.

Kodelja, B., Žebre, M., Stepišnik, U., 2013. Poledenitev Trnovskega gozda. Ljubljana, Filozofska fakulteta, Oddelek za geografijo (E-GeograFF 6), 63 str. URL: http://geo. ff.uni-lj.si/sites/default/files/12/e-geograff_6_poledenitev_trnovskega_gozda.pdf (Citirano 21. 10. 2013). 
Magaš, D., 2002. Natural-geographic characteristics of the Boka Kotorska area as the basis of development. Geoadria, 7, 1, str. 51-81.

Manley, G., 1955. On the occurrence of ice domes and permanently snow-covered summits. Journal of glaciology, 17, str. 453-456.

Matić, N., Maldini, K., Cuculić, V., Frančišković-Bilinski, S., 2012. Investigations of karstic springs of the Biokovo Mt from the Dinaric karst of Croatia. Chemie der Erde - Geochemistry, 72, 2, str. 179-190.

Meier, M. F., Post, A. S., 1962. Recent variations in mass net budgets of glaciers in western North America. International Association of scientific hydrology, 58, str. 63-77.

Meierding, T. C., 1982. Late Pleistocene glacial equilibrium-line altitudes in the Colorado Front Range: a comparison of methods. Quaternary research, 18, 3, str. 289-310.

Osnovna geološka karta SFRJ. List Imotski. 1978. 1 : 100.000. Beograd, Zvezni geološki zavod.

Osnovna geološka karta SFRJ. List Omiš. 1977. 1 : 100.000. Beograd, Zvezni geološki zavod.

Osnovna geološka karta SFRJ. List Ploče. 1979. 1 : 100.000. Beograd, Zvezni geološki zavod.

Østrem, G., 1966. The height of the glaciation limit in southern British Columbia and Alberta. Geografiska annaler. Series A, Physical geography, 48, 3, str. 126-138.

Porter, S. C., 1975. Glaciation limit in New Zealand's Southern Alps. Arctic and Alpine research, 7, 1, str. 33-37.

Porter, S. C., 2000. Snowline depression in the tropics during the last glaciation. Quaternary science reviews, 20, str. 1067-1091.

Protrka, K., Velić, J., Škrabić, H., Velić, I., 2011. Glacijalna sedimentna tijela u Bukovačkoj dragi, SZ Biokovo. V: Srzić, S. (ur.). Znanstveno-stručni skup "Biokovo na razmeđi milenija: razvoj parka prirode u 21. stoljeću” - Knjiga sažetaka. Makarska, Javna ustanova "Park prirode Biokovo", str. 71-72.

Radovanović, M., 1994. Pluviometrijske karakteristike NP Lovćen. V: Mijušković, M. (ur.). Nacionalni park "Lovćen” - prirodna i kulturna dobra. Cetinje, 17.-18. septembar 1993. Podgorica, Crnogorska akademija nauka i umjetnosti, str. 27-37.

Roglić, J., 1931. Glacijalni tragovi na Biokovu. Posebno izdanje Srpskog geografskog društva, 10, str. 49-51.

Roglić, J., 1935. Biokovo: geomorfološka ispitivanja. Beograd, Mlada Srbija, 96 str.

Roglić, J., 2005. Geomorfološke teme. Zagreb, Prirodoslovno-matematički fakultet, 558 str.

Sissons, J. B., 1974. A late-glacial ice cap in the central Grampians, Scotland. Transactions of the Institute of British geographers, 62, str. 95-114.

Stepišnik, U., Ferk, M., Kodelja, B., Medenjak, G., Mihevc, A., Natek, K., Žebre, M., 2009. Glaciokarst of western Orjen, Montenegro. Cave and karst science, 36, 1, str. 21-28.

Stepišnik, U., Žebre, M., 2011. Glaciokras Lovčena (E-GeografFF 2). Ljubljana, Znanstvena založba Filozofske fakultete, Oddelek za geografijo, 82 str. URL: http://geo. ff.uni-lj.si/sites/default/files/glaciokras_lovcena_0.pdf(Citirano 5. 2. 2013).

Telbisz, T., Dragušica, H., Nagy, B., 2009. Doline morphometric analysis and karst morphology of Biokovo Mt (Croatia) based on field observations and digital terrain analysis. Hrvatski geografski glasnik, 71, 2, str. 5-22. 


\section{PLEISTOCENE GLACIATION OF THE BIOKOVO MASSIF}

\section{Summary}

The Biokovo massif is located in central Dalmatia, Croatia, and it is a part of the Dinaric Mountains. It lies between the Omiška Dinara massif to the northwest, lowered terrain

between villages Žeževica, Rastovac, Župa and Raščane to the northeast, the Rilič massif to the southeast and Adriatic Sea to the southwest. Length of the Biokovo massif is about $36 \mathrm{~km}$, width at its widest point is $9.5 \mathrm{~km}$. The highest peak Sveti Jure with an altitude of $1762 \mathrm{~m}$ significantly exceeds the plateau of Biokovo at altitudes between 1300 to $1400 \mathrm{~m}$. The whole area of Biokovo is karstified; surface is dominated by dense pattern of various karst depressions and individual conic hills. At the highest section of the massif evidences of glacial erosion and accumulation were stated by Roglić (1931; 1935). Some authors identified glaciogenic features on much lower altitudes (Telbisz, Dragušica, Nagy, 2009; Protrka et al., 2011).

The aim of this research was reinterpretation of previous findings about glaciation of Biokovo. During morphographic mapping of the area various glacial features and related sediments were identified. Since morpho-chronological analysis of glaciogenic deposits were not conducted within our research, we compared the type and spatial distribution of the deposits with similar features on some other mountain ranges along the Adriatic coast. Results from Orjen and some other mountain ranges in the central part of Montenegro (Hughes et al., 2010; Hughes et al., 2011) have shown that the most extensive glaciation occurred during the Middle Pleistocene while in the Late Pleistocene glaciation was limited to cirques and valleys. According to the lithification of glaciogenic deposits, we hypothetically linked lithified and well corroded deposits to the Middle Pleistocene glaciations (MIS 12 and MIS 6) while well preserved moraine ridges of non-lithified deposits to the Late Pleistocene glacial events (MIS 5d-2). Moreover, lithified deposits extend over much wider area of the massif while non-lithified are limited only to smaller area indicating larger scale of Middle Pleistocene glaciations. All further reconstructions of glaciers and equilibrium line altitudes were carried out on the basis of the morphographic and morphometric analysis of Late Pleistocene non-lithified glacial accumulations.

Evidences of the Late Pleistocene glaciation were identified northeast of the peak Sveti Jure approximately at the same extent as defined by Roglić (1931). Elsewhere, despite the statements of earlier literature (Protrka et al., 2011; Telbisz, Dragušica, Nagy, 2009) we found no glacial landforms.

We made the reconstruction of glacial topography on the basis of morphographic and morphometric data. The results show that during Late Pleistocene Biokovo hosted two cirque glaciers to the north-east of the highest peak, occupying an area of about $0.8 \mathrm{~km}^{2}$, which is largely consistent with research of Roglić $(1931 ; 1935)$.

The equilibrium line altitude was established by accumulation-area ratio, median elevation of glaciers and area-weighted mean altitude methods. The average Late Pleistocene equilibrium line altitude was calculated to $1515 \mathrm{~m}$, which is $55 \mathrm{~m}$ below the value defined 
by Roglić $(1931 ; 1935)$. Equilibrium line altitude of the Biokovo is approximately 200 to $300 \mathrm{~m}$ higher compared to Velebit, Orjen and Lovćen massifs (Belij, 1985; Bognar et al., 1991; Bognar, Faivre, 2006; Hughes et al., 2010; Stepišnik et al., 2009; Stepišnik, Žebre, 2011 ) in the coastal part of the Dinaric Mountains. This can be explained by the significantly lower amount of precipitation recorded on Biokovo compared to other coastal mountains. Precipitation on the highest parts of Biokovo is around $2500 \mathrm{~mm}$, on Velebit about $3500 \mathrm{~mm}$, while Orjen and Lovćen receive over $4500 \mathrm{~mm}$.

(Translated by Uroš Stepišnik) 
